\title{
Bioaugmentation of Lactobacillus delbrueckii ssp. bulgaricus TISTR 895 to enhance bio-hydrogen production of Rhodobacter sphaeroides KKU-PS5
}

\author{
Sucheera Laocharoen ${ }^{1}$, Alissara Reungsang ${ }^{1,2^{*}}$ and Pensri Plangklang ${ }^{1}$
}

\begin{abstract}
Background: Bioaugmentation or an addition of the desired microorganisms or specialized microbial strains into the anaerobic digesters can enhance the performance of microbial community in the hydrogen production process. Most of the studies focused on a bioaugmentation of native microorganisms capable of producing hydrogen with the dark-fermentative hydrogen producers while information on bioaugmentation of purple non-sulfur photosynthetic bacteria (PNSB) with lactic acid-producing bacteria (LAB) is still limited. In our study, bioaugmentation of Rhodobacter sphaeroides KKU-PS5 with Lactobacillus delbrueckil ssp. bulgaricus TISTR 895 was conducted as a method to produce hydrogen. Unfortunately, even though well-characterized microorganisms were used in the fermentation system, a cultivation of two different organisms in the same bioreactor was still difficult because of the differences in their metabolic types, optimal conditions, and nutritional requirements. Therefore, evaluation of the physical and chemical factors affecting hydrogen production of PNSB augmented with LAB was conducted using a full factorial design followed by response surface methodology (RSM) with central composite design (CCD).

Results: A suitable LAB/PNSB ratio and initial cell concentration were found to be $1 / 12(\mathrm{w} / \mathrm{w})$ and $0.15 \mathrm{~g} / \mathrm{L}$, respectively. The optimal initial pH, light intensity, and Mo concentration obtained from RSM with CCD were $7.92,8.37 \mathrm{klux}$ and $0.44 \mathrm{mg} / \mathrm{L}$, respectively. Under these optimal conditions, a cumulative hydrogen production of $3396 \pm 66 \mathrm{~mL} \mathrm{H} / \mathrm{L}$, a hydrogen production rate (HPR) of $9.1 \pm 0.2 \mathrm{~mL} \mathrm{H} / \mathrm{L} h$, and a hydrogen yield (HY) of $9.65 \pm 0.23 \mathrm{~mol} \mathrm{H}_{2} / \mathrm{mol}$ glucose were obtained. KKU-PS5 augmented with TISTR 895 produced hydrogen from glucose at a relatively high $\mathrm{HY}, 9.65 \pm 0.23 \mathrm{~mol} \mathrm{H}_{2} /$ mol glucose, i.e., $80 \%$ of the theoretical yield.
\end{abstract}

Conclusions: The ratio of the strains TISTR 895/KKU-PS5 and their initial cell concentrations affected the rate of lactic acid production and its consumption. A suitable LAB/PNSB ratio and initial cell concentration could balance the lactic acid production rate and its consumption in order to avoid lactic acid accumulation in the fermentation system. Through use of appropriate environmental conditions for bioaugmentation of PNSB with LAB, a hydrogen production could be enhanced.

Keywords: Bio-hydrogen, Purple non-sulfur photosynthetic bacteria, Dark fermentative bacteria, Lactic acidproducing bacteria

\section{Background}

Hydrogen is a valuable alternative fuel and energy carrier as it has a high energy content, $122 \mathrm{~kJ} / \mathrm{g}$, which is 2.75

\footnotetext{
*Correspondence: alissara@kku.ac.th

${ }^{1}$ Department of Biotechnology, Faculty of Technology, Khon Kaen

University, Khon Kaen 40002, Thailand

Full list of author information is available at the end of the article
}

times higher than that of hydrocarbon fuels [1]. Biological hydrogen production is considered an environmentally friendly process because the operations to produce hydrogen from biomass and waste materials are conducted under mild conditions $[2,3]$. In addition, only water is formed when hydrogen is burned as a fuel or is used to generate electricity [4]. Dark and photo-hydrogen 
production are the primary methods of biological hydrogen production. In dark fermentation, the fermentative bacteria used organic substances as the sole source of energy and electrons for the metabolic activities and hydrogen production, while photo-fermentation uses organic substrates as electron donors and light as an energy source $[5,6]$.

Photo-fermentative hydrogen production was found in purple non-sulfur photosynthetic bacteria (PNSB). The photosystem of PNSB is located in the cell membrane and contains light-harvesting pigments, bacteriochlorophyll and carotenoids, as well as an associated electron transport chain [7]. Light energy is absorbed by two light-harvesting complexes that are referred as "core" (light-harvesting complex 1; LH1) and "peripheral" (lightharvesting complex 2; LH2) antenna complexes. These two complexes are channeled into the reaction complex which initiates a cyclic electron flow through several electron carriers $[6,7]$. The electrochemical proton gradient is generated during the photosynthetic process of PNSB. A proton gradient is used to drive adenosine triphosphate (ATP) synthesis by ATP synthase and is also used to produce a reduced ferredoxin $\left[\mathrm{Fd}_{(\text {red })}\right]$ by reversed electron flow $[6,8]$. ATP and $\mathrm{Fd}_{(\text {red }}$ are needed for reducing protons to hydrogen by the activity of nitrogenase $[6$, 7], which is the key enzyme for the hydrogen production process of PNSB. The nitrogenase side reaction is showed in Eq. (1). The electron sink pathways for competing the hydrogen production process by PNSB are carbon dioxide fixation and polyhydroxybutyrate (PHB) synthesis [5].

$$
2 H^{+}+F d_{(r e d)}\left(2 e^{-}\right)+4 A T P \underset{\text { Nitrogenase }}{\longrightarrow} H_{2}+4\left(A D P+P_{i}\right)
$$

The improvement of the efficiency of hydrogen production can be conducted using various approaches such as genetic engineering to introduce the hydrogen generation pathway and to eliminate the competition metabolisms with hydrogen production of microorganism [9, $10]$ as well as the integration of dark and photo-fermentation system [11-15]. In addition, the bioaugmentation or an addition of the desired microorganisms or specialized microbial strains into the anaerobic digesters can enhance the performance of microbial community in the hydrogen production process. Previous researches demonstrated the effectiveness of bioaugmentation in improving hydrogen production [16-23]. Kuo et al. [17] found that a hydrogen production potential in a 2-phase bio-hydrogen and bio-methane production from vegetable-based kitchen waste and Napier grass increased drastically after the bioaugmentation of Clostridium sp. TCW1. Marone et al. [18] reported that the bioaugmentation of indigenous microbial communities in vegetable waste with three hydrogen-producing strains viz., Buttiauxella sp. 4, Rahnella sp. 10, and Raoultella sp. 47 using each single strain and mixed three strains together significantly increased the hydrogen yield (HY) and the hydrogen production rate (HPR) in comparison to nonbioaugmentation. Bioaugmentation would not only improve the hydrogen production process but also can be used to overcome the inhibition occurred in the hydrogen production process. Goud et al. [16] reported that the bioaugmentation of native acidogenic microflora with Bacillus subtilis, Pseudomonas stutzeri, and Lysinibacillus fusiformis could increase substrate degradation rate and enhance fermentative hydrogen production from realfield food wastewater at elevated organic load. In addition, the bioaugmentation strategies could shorten the digestion time in a bioreactor. For example, Ma et al. [19] found that the bioaugmentation of the activated sludge with mixed cultures of specialized bacteria consisting of Pseudomonas, Bacillus, Acinetobacter, Flavobacterium, and Micrococcus in a contact oxidation process decreased the chemical oxygen demand (COD) and ammonia nitrogen $\left(\mathrm{NH}^{4+}-\mathrm{N}\right)$ from $320-530 \mathrm{mg} / \mathrm{L}$ and $8-25 \mathrm{mg} / \mathrm{L}$ to below 80 and $10 \mathrm{mg} / \mathrm{L}$, respectively, within 20 days, while the un-bioaugmented conventional activated sludge process spent 30 days. From the discussion above, we can see that the bioaugmentation methods are successfully used in dark hydrogen fermentation process or methane production process, while there is very limited information on the application of bioaugmentation in the dark- and photo-hydrogen fermentation processes.

In dark- and photo-hydrogen fermentation processes, a dark fermentation is done before photo fermentation in which effluent of the dark fermentation is used as substrate by photo-fermentative bacteria in a second reactor. Dark fermentation by acidogenic-anaerobic bacteria produces hydrogen concomitantly with soluble metabolites, i.e., volatile fatty acids (VFAs) and alcohols [24]. The VFAs obtained from a dark fermentation process can be further used by photo-fermentative bacteria to produce hydrogen $[12,25]$. However, the effluent of a dark fermentation must be treated before being subjected to photo fermentation to meet metabolic conditions for effective photo fermentation. Treatments, including dilution, nutrient addition, $\mathrm{pH}$ adjustment, and centrifugation all require energy-intensive inputs and are costly. In contrast, the bioaugmentation of PNSB into darkfermentation process does not require these treatment processes because dark- and photo-fermentative bacteria are cocultured in the same reactor. VFAs produced from dark fermentation are immediately converted to hydrogen by photo-fermentative bacteria. This can also prevent accumulation of VFAs in the medium [26]. Thus, the fermentation time of bioaugmentation approach can be 
shortened which leads to an improvement in hydrogen productivity. Acetate and butyrate, the soluble metabolites commonly found in dark fermentation, can be easily converted into acetyl units, without formation of pyruvate, during the metabolism of PNSB. The acetyl units are mainly converted to polyhydroxyalkanoates (PHAs) via 3 ketothiolase, acetoacetyl-CoA reductase, and PHA synthase resulting in an accumulation of PHAs in PNSB rather than hydrogen production [27, 28]. Among the VFAs produced by dark fermentation, lactate is found to be a more suitable substrate for hydrogen production by PNSB than acetate and butyrate since lactate can be directly converted to pyruvate via lactate dehydrogenase. Pyruvate can be further catalyzed for ATP production in the Krebs cycle in which ATP is necessary for hydrogen production process $[28,29]$. Therefore, in this study, a bioaugmentation of lactic acid-producing bacteria (LAB), i.e., Lactobacillus delbrueckii ssp. bulgaricus TISTR 895 into photo-fermentation process from glucose by PNSB, Rhodobacter sphaeroides KKU-PS5, was conducted in order to achieve maximum hydrogen production. The strain TISTR 895 is a homo-fermentative LAB. It produces lactate as its sole end-product [30,31], while the strain, KKU PS5, is able to produce hydrogen from lactate [32].

The homo-fermentative LAB theoretically produces two moles of lactic acid from one mole of glucose [Eq. (2)] in which glucose is catalyzed to pyruvate through glycolysis and then pyruvate is reduced to lactic acid by lactate dehydrogenase of LAB [33]. Thereafter, PNSB consumes lactate as an electron donor (Eq. 3). Electrons from lactate are transferred to oxidized form of ferredoxin $\left[\mathrm{Fd}_{(\mathrm{ox})}\right]$ through a series of membrane-bound electron transport carrier molecules [8], and then $\mathrm{Fd}_{(\mathrm{red})}$ molecules are used to reduce protons to produce hydrogen by nitrogenase as shown in Eq. (4). Therefore, the overall maximum theoretical $\mathrm{HY}$ is as high as $12 \mathrm{~mol} \mathrm{H}_{2} / \mathrm{mol}$ hexose as shown in Eqs. (2) and (3) [34].

$$
\mathrm{C}_{6} \mathrm{H}_{12} \mathrm{O}_{6} \underset{\text { Lactic acid-producing bacteria }}{\longrightarrow} 2 \mathrm{C}_{3} \mathrm{H}_{6} \mathrm{O}_{3}
$$

$2 \mathrm{C}_{3} \mathrm{H}_{6} \mathrm{O}_{3}+6 \mathrm{H}_{2} \mathrm{O} \underset{\text { Purple non-sulfur photosynthetic bacteria }}{\longrightarrow} 12 \mathrm{H}_{2}+6 \mathrm{CO}_{2}$

$$
\left(C_{3} H_{6} \mathrm{O}_{3}\right) \underset{A T P \uparrow}{\longrightarrow} F d_{(\text {red })} \underset{A T P \uparrow}{\longrightarrow} \text { Nitrogenase } \rightarrow H_{2}
$$

A cultivation of two different organisms in the same bioreactor with proper conditions for both types of bacteria is difficult. This is because they are different in their metabolic types, optimal conditions, and nutritional requirements. The ratio of the number of dark- and photo-fermentative bacteria is an important factor for obtaining an appropriate match in growth and substrate utilization, which directly affects the rate of hydrogen production and the HY [35]. Initial cell concentration has a dramatic effect on the HPR. Too low a cell concentration causes a long lag time and slow fermentation, while too high a cell concentration causes a low HY [36]. The initial $\mathrm{pH}$ affects nitrogenase activity, the proton motive force of PNSB, and cell growth. These functions are responsible for hydrogen production [37]. Light intensity is another important factor since light is the sole energy source for ATP synthesis via photophosphorylation by PNSB during photo-hydrogen production under anaerobic conditions [38]. Molybdenum (Mo) is an important cofactor for the synthesis of nitrogenase $[39,40]$. In light of the aforementioned information, there is a need to optimize these key factors to obtain suitable conditions for effective hydrogen production.

Hydrogen production from waste not only reduces pollution, but also reclaims renewable energy. However, the bottlenecks of hydrogen production from wastes are its low production rate and HY [41]. These problems may be solved by selecting and using effective organisms, an appropriate bacterial ratio, and cell concentration as well as suitable environmental conditions [41]. Therefore, the use of the optimal conditions in a bioaugmentation system well-characterized microorganisms using glucose as a model substrate can pave the way toward the development of an efficient hydrogen production process from sugar-containing wastes such as dairy industry residues, effluents of food processing plants, and sugar-refining (molasses) residues [5].

In this study, the important factors for bioaugmentation of PNSB, KKU-PS5, with LAB, TISTR 895, to produce hydrogen were optimized. The optimal LAB/PNSB bacterial ratio and initial cell concentration were investigated using a full factorial design followed by response surface methodology (RSM) with central composite design (CCD) for optimization of initial $\mathrm{pH}$, light intensity, and Mo concentration.

\section{Results and discussion}

\section{Optimization of LAB/PNSB ratio and initial cell} concentration for bio-hydrogen production

Cumulative hydrogen production, HPR, and HY at different LAB/PNSB bacterial ratios and initial cell concentrations are given in Table 1 . The results show that hydrogen was not produced at a LAB/PNSB ratio of $1 / 1$ (Condition A) at any initial cell concentration (Conditions A1-A5). This is because LABs grow very much faster than PNSBs. Hence, at a LAB/PNSB ratio of $1 / 1$, PNSBs were unable to consume lactic acid rapidly enough to prevent its 
Table 1 Cumulative hydrogen production, hydrogen production rate (HPR), and hydrogen yield (HY) at different lactic acid-producing bacteria/purple non-sulfur photosynthetic bacteria (LAB/PNSB) ratios and initial cell concentration

\begin{tabular}{|c|c|c|c|c|c|c|c|}
\hline Condition & $\begin{array}{l}\text { LAB/PNSB } \\
\text { ratio }(w / w)\end{array}$ & $\begin{array}{l}\text { Initial cell conc. } \\
\text { (g/L) }\end{array}$ & $\begin{array}{l}\text { LAB conc. } \\
\text { (g/L) }\end{array}$ & $\begin{array}{l}\text { PNSB conc. } \\
\text { (g/L) }\end{array}$ & $\begin{array}{l}\text { Cumulative } \mathrm{H}_{2} \\
\text { production }\left(\mathrm{ml} \mathrm{H}_{2} / \mathrm{L}\right)\end{array}$ & $\mathrm{HPR}\left(\mathrm{ml} \mathrm{H}_{2} / \mathrm{L} \mathrm{h}\right)$ & $\begin{array}{l}\mathrm{HY}\left(\mathrm{mol} \mathrm{H}_{2} /\right. \\
\text { mol glucose })\end{array}$ \\
\hline \multicolumn{8}{|l|}{$A$} \\
\hline A1 & $1: 1$ & 0.05 & 0.025 & 0.025 & 0 & 0 & 0 \\
\hline$A 2$ & & 0.10 & 0.050 & 0.050 & 0 & 0 & 0 \\
\hline $\mathrm{A} 3$ & & 0.15 & 0.075 & 0.075 & 0 & 0 & 0 \\
\hline A4 & & 0.20 & 0.100 & 0.100 & 0 & 0 & 0 \\
\hline A5 & & 0.25 & 0.125 & 0.125 & 0 & 0 & 0 \\
\hline \multicolumn{8}{|l|}{$B$} \\
\hline B1 & $1: 2$ & 0.05 & 0.017 & 0.033 & $1355 \pm 113$ & $2.1 \pm 0.2$ & $3.01 \pm 0.25$ \\
\hline B2 & & 0.10 & 0.033 & 0.067 & $721 \pm 65$ & $1.3 \pm 0.1$ & $1.58 \pm 0.11$ \\
\hline B3 & & 0.15 & 0.050 & 0.100 & 0 & 0 & 0 \\
\hline B4 & & 0.20 & 0.067 & 0.133 & 0 & 0 & 0 \\
\hline B5 & & 0.25 & 0.083 & 0.167 & 0 & 0 & 0 \\
\hline \multicolumn{8}{|l|}{ C } \\
\hline $\mathrm{C} 1$ & $1: 7$ & 0.05 & 0.066 & 0.044 & $1662 \pm 41$ & $3.1 \pm 0.1$ & $4.84 \pm 0.11$ \\
\hline$C 2$ & & 0.10 & 0.013 & 0.088 & $1460 \pm 107$ & $2.9 \pm 0.2$ & $4.00 \pm 0.34$ \\
\hline $\mathrm{C} 3$ & & 0.15 & 0.019 & 0.131 & $1336 \pm 56$ & $2.7 \pm 0.2$ & $3.65 \pm 0.25$ \\
\hline C4 & & 0.20 & 0.025 & 0.175 & $1403 \pm 153$ & $2.6 \pm 0.3$ & $3.39 \pm 0.41$ \\
\hline $\mathrm{C} 5$ & & 0.25 & 0.031 & 0.219 & $1359 \pm 129$ & $2.6 \pm 0.2$ & $3.12 \pm 0.20$ \\
\hline \multicolumn{8}{|l|}{$D$} \\
\hline D1 & $1: 12$ & 0.05 & 0.004 & 0.046 & $1613 \pm 69$ & $3.1 \pm 0.1$ & $4.44 \pm 0.19$ \\
\hline D2 & & 0.10 & 0.008 & 0.092 & $1590 \pm 38$ & $3.0 \pm 0.1$ & $4.47 \pm 0.11$ \\
\hline D3 & & 0.15 & 0.012 & 0.138 & $1833 \pm 72$ & $3.6 \pm 0.3$ & $5.93 \pm 0.23$ \\
\hline D4 & & 0.20 & 0.015 & 0.185 & $1587 \pm 86$ & $3.6 \pm 0.2$ & $5.84 \pm 0.30$ \\
\hline D5 & & 0.25 & 0.019 & 0.231 & $1573 \pm 96$ & $3.6 \pm 0.2$ & $5.82 \pm 0.32$ \\
\hline
\end{tabular}

accumulation. Accumulation of lactic acid can reduce the $\mathrm{pH}$ low enough to adversely affect the growth of PNSBs and its consumption of VFAs, as well as inhibiting nitrogenase [15]. When the LAB/PNSB ratio was $1 / 2$ (Condition $\mathrm{B})$, hydrogen production occurred at the initial cell concentration of 0.05 (Condition B1) and $0.10 \mathrm{~g} / \mathrm{L}$ (Condition B2). However, when the initial cell concentration was further increased to 0.15 (Condition B3), 0.20 (Condition B4), and $0.25 \mathrm{~g} / \mathrm{L}$ (Condition B5), hydrogen was not produced. At a low initial cell concentration of 0.05 (Condition B1) and $0.10 \mathrm{~g} / \mathrm{L}$ (Condition B2), lactic acid in the fermentation broth was at concentrations of 0.4 and $0.6 \mathrm{~g} / \mathrm{L}$, respectively, while at a higher initial cell concentration of $0.15-0.25 \mathrm{~g} / \mathrm{L}$ (Conditions B3-B5), lactic acid concentration in the fermentation broth was high (1.7$2.3 \mathrm{~g} / \mathrm{L}$ ) (Additional file 1). These results implied that when the initial cell concentrations were increased, the consumption rate of lactic acid by PNSB was lower than the rate of lactic acid production by $\mathrm{LAB}$, which led to lactic acid accumulation, resulting in a decrease in hydrogen production.
At a $\mathrm{LAB} / \mathrm{PNSB}$ ratio of $1 / 7$ (Condition $\mathrm{C}$ ), hydrogen was produced at every initial cell concentration (Conditions $\mathrm{C} 1-\mathrm{C} 5$ ). However, HPR and HY decreased with an increase in initial cell concentration from 0.05 (Condition C1) to $0.25 \mathrm{~g} / \mathrm{L}$ (Condition C5). Cumulative hydrogen production, HPR, and HY were maximized at an initial cell concentration of $0.05 \mathrm{~g} / \mathrm{L}$ (Condition $\mathrm{C} 1$ ). We found that at an initial cell concentration of $0.05 \mathrm{~g} / \mathrm{L}$ (Condition $\mathrm{C} 1$ ), lactic acid concentration in fermentation broth was very low at $0.03 \mathrm{~g} / \mathrm{L}$, while at a high initial cell concentration of $0.10-0.25 \mathrm{~g} / \mathrm{L}$ (Conditions C2-C5), lactic acid concentration was 10-14 times higher (Additional file 2). These results caused low hydrogen production due to the negative effect of high lactic acid concentration on hydrogen production. Even though the amount of PNSB increased with an increase in the amount of LABs at the same bacterial ratio, hydrogen production was decreased. Therefore, when two cultures were used to produce hydrogen, not only the optimal LAB/PNSB ratio, but also the initial cell concentration should be optimized in order to overcome lactic acid accumulation in the fermentation system. 
Based on our findings, we further investigated the effect of PNSB concentration on hydrogen production at a fixed initial LAB concentration of $0.03 \mathrm{~g} / \mathrm{L}$ and LAB/ PNSB ratios of $1 / 2$ and $1 / 7$. Figure 1 shows the timecourse profiles of hydrogen production, cell, glucose, and metabolite (lactic acid, formic acid) concentrations of LAB fermentation at an initial LAB concentration of 0.03 g/L (Fig. 1a); PNSB augmented with LAB at a LAB/ PNSB ratio of $1 / 2$ with a LAB concentration of $0.033 \mathrm{~g} / \mathrm{L}$ and a PNSB concentration of $0.067 \mathrm{~g} / \mathrm{L}$ (Fig. 1b) (Condition B2); and PNSB augmented with LAB at a LAB/PNSB ratio of $1 / 7$ with a $\mathrm{LAB}$ concentration of $0.031 \mathrm{~g} / \mathrm{L}$ and a PNSB concentration of $0.219 \mathrm{~g} / \mathrm{L}$ (Fig. 1c) (Condition C5). Approximately $1.8 \mathrm{~g} / \mathrm{L}$ of lactic acid was produced by LAB (Fig. 1a) with $2.1 \mathrm{~g} / \mathrm{L}$ of glucose utilized, or $86 \%$ of the substrate was consumed for lactic acid formation by LAB (Fig. 1a). LAB concentration was increased from 0.03 to approximately $0.25 \mathrm{~g} / \mathrm{L}$. The results suggested that glucose was consumed by LAB to produce lactic acid and to maintain the cells without hydrogen production. Augmentation of $\mathrm{LAB}$ in the system at a $\mathrm{LAB} / \mathrm{PNSB}$ ratio of $1 / 2$ produced hydrogen at $721 \pm 65 \mathrm{~mL} \mathrm{H}_{2} / \mathrm{L}$ (Fig. 1b). Under this condition, lactic acid accumulated in the fermentation broth to about $0.66 \pm 0.06 \mathrm{~g} / \mathrm{L}$, indicating that the amount of PNSB $(0.067 \mathrm{~g} / \mathrm{L})$ added in the system was not high enough to balance the rate of lactic acid production and its consumption. When the concentration of PNSB was increased to $0.219 \mathrm{~g} / \mathrm{L}$ at a LAB/PNSB ratio of $1 / 7$ (Fig. 1c), hydrogen production increased to $1359 \pm 129 \mathrm{~mL} \mathrm{H}_{2} / \mathrm{L}$, which was approximately two times higher than when the $\mathrm{LAB} / \mathrm{PNSB}$ ratio was $1 / 2$. The concentration of residual lactic acid in the fermentation broth was low. In addition, not only lactic acid was used as substrate to produce hydrogen by PNSB, but also glucose. Increasing the PNSB level at this $\mathrm{LAB} / \mathrm{PNSB}$ ratio produced a higher lactic acid consumption rate, which in turn reduced lactic acid accumulation. Therefore, at a fixed LAB concentration, the cell concentration of PNSB could become a limiting factor for hydrogen production in a bioaugmentation system.

Maximum hydrogen production was obtained at a $\mathrm{LAB} / \mathrm{PNSB}$ ratio of $1 / 12$ (Condition D). Cumulative hydrogen production, HPR, and HY were increased as the initial cell concentration was increased from 0.05 to $0.15 \mathrm{~g} / \mathrm{L}$ (Conditions D1-D3). However, hydrogen production decreased, while the HPR remained the same when the initial cell concentration was greater than $0.15 \mathrm{~g} / \mathrm{L}$ (Conditions D4, D5) (Table 1). A maximum cumulative hydrogen production, HPR, and $\mathrm{HY}$ of $1833 \pm 72 \mathrm{~mL} \mathrm{H}_{2} / \mathrm{L}, 3.6 \pm 0.3 \mathrm{~mL} \mathrm{H}_{2} / \mathrm{L} \mathrm{h}$ and $5.93 \pm 0.23 \mathrm{~mol} \mathrm{H}_{2} / \mathrm{mol}$ glucose, respectively, were obtained at an initial cell concentration of $0.15 \mathrm{~g} / \mathrm{L}$ (Condition D3). These results indicate that at a $\mathrm{LAB} / \mathrm{PNSB}$ ratio of $1 / 12$, the amounts of LAB and PNSB were suitable for balancing the rate of lactic acid production by $\mathrm{LAB}$ and the rate of lactic acid consumption by PNSB without lactic acid accumulation. A decrease in hydrogen production at initial cell concentrations less than $0.15 \mathrm{~g} / \mathrm{L}$, at a LAB/PNSB ratio of $1 / 12$, may be due to low cell concentrations. Furthermore, the reduction of hydrogen production seen at initial cell concentrations above $0.15 \mathrm{~g} / \mathrm{L}$ may have been caused by consumption of available lactic acid and glucose for cell growth [15]. In addition, the shading effect caused by high cell concentrations could lead to a low hydrogen production [42].

The optimal dark and photo bacterial ratios are quite different from study to study. Liu et al. [15] reported that an optimal dark/photo bacterial ratio of C. butyricum/Rhodopseudomonas faecalis RLD-53 for maximal hydrogen production was $1 / 2$. Argun et al. [43] reported that a dark/photo bacterial ratio (anaerobic sludge/mixture of Rhodobacter sp.) of $1 / 2$ gave the lowest hydrogen production, while a dark/photo bacterial ratio of $1 / 7$ was a suitable ratio. The differences in types of microorganisms, substrates used, and culture conditions may have contributed to these findings.

\section{Hydrogen production under the optimal LAB/PNSB ratio and initial cell concentration}

We conducted experiments to investigate the effects of LAB only, PNSB only, and PNSB augmented with $\mathrm{LAB}$ on cumulative hydrogen production, biomass, glucose, and VFA concentrations under the optimal LAB/ PNSB ratio of $1 / 12$ and an initial cell concentration of $0.15 \mathrm{~g} / \mathrm{L}$. The results demonstrated that LABs cultured alone consumed glucose for cell maintenance and produced lactic acid as their primary product without hydrogen production (Fig. 2a). PNSB cultured alone consumed glucose for cell growth and hydrogen production with the cumulative hydrogen production, HPR, and $\mathrm{HY}$ of $1682 \pm 76 \mathrm{~mL} \mathrm{H}_{2} / \mathrm{L}, 3.2 \pm 0.1 \mathrm{~mL} \mathrm{H}_{2} / \mathrm{L} \mathrm{h}$, and $4.38 \pm 0.20 \mathrm{~mol} \mathrm{H}_{2} / \mathrm{mol}$ glucose, respectively (Fig. 2b). Formic acid was found in the hydrogen fermentation by PNSB (Fig. 2b). Normally, under light illumination, PNSB will not produce formic acid. However, our results showed that formic acid was produced at approximately $0.4 \mathrm{~g} / \mathrm{L}$ (Fig. 2b) in the PNSB only fermentation. This may have been caused by high cell concentrations (approximately $1.8 \mathrm{~g} / \mathrm{L}$ ) (Fig. 2b) which could make the medium opaque, restricting light from entering the serum bottle, resulting in a light-limited condition in the system. Therefore, the metabolism of KKU-PS5 to metabolize glucose might have adapted to dark or limited light conditions resulting in formic acid formation. Our results are similar to the findings of Eroglu et al. [44] who found that under limited illumination, hydrogen was not produced 

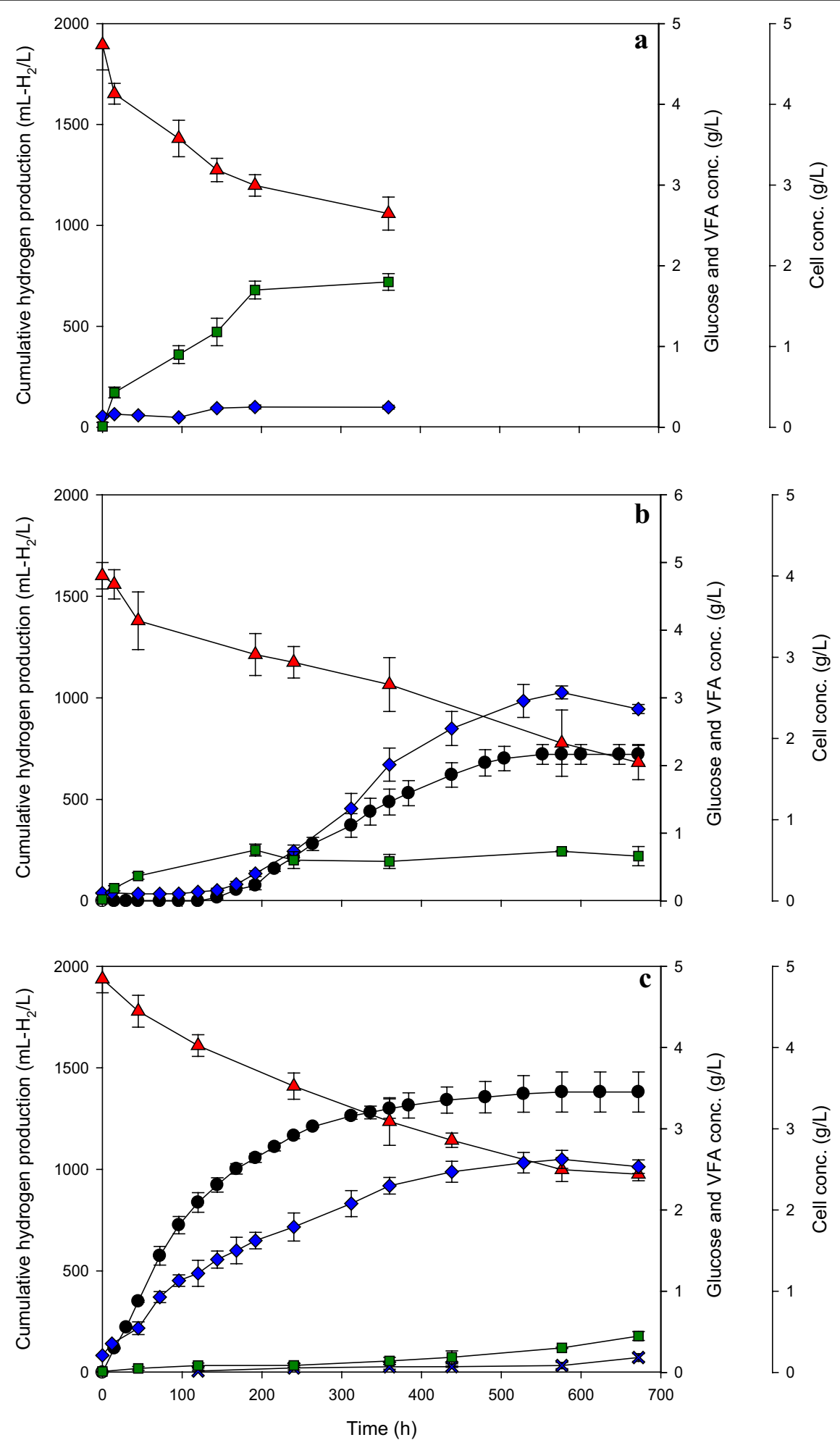

Fig. 1 Variations of cumulative hydrogen production, concentration of cell, glucose, and volatile fatty acids over time under various lactic acidproducing bacteria/purple non-sulfur photosynthetic bacteria ( $L A B / P N S B)$ ratios and a fix $L A B$ concentration of $0.03 \mathrm{~g} / \mathrm{L}$. $L A B$ only (LAB concentration $=0.03 \mathrm{~g} / \mathrm{L})(\mathbf{a}) ; \mathrm{LAB} / \mathrm{PNSB}$ ratio of $1 / 2(\mathrm{LAB}$ concentration $=0.033 \mathrm{~g} / \mathrm{L}, \mathrm{PNSB}$ concentration $=0.067 \mathrm{~g} / \mathrm{L})(\mathbf{b}) ; \mathrm{LAB} / \mathrm{PNSB}$ ratio of $1 / 7(\mathrm{LAB}$ concentration $=0.031 \mathrm{~g} / \mathrm{L}, \mathrm{PNSB}$ concentration $=0.219 \mathrm{~g} / \mathrm{L})(\mathbf{c})$. Hydrogen (black circle), glucose (red triangle), cell (blue diamond), lactic acid (green square), formic acid (blue cross) 

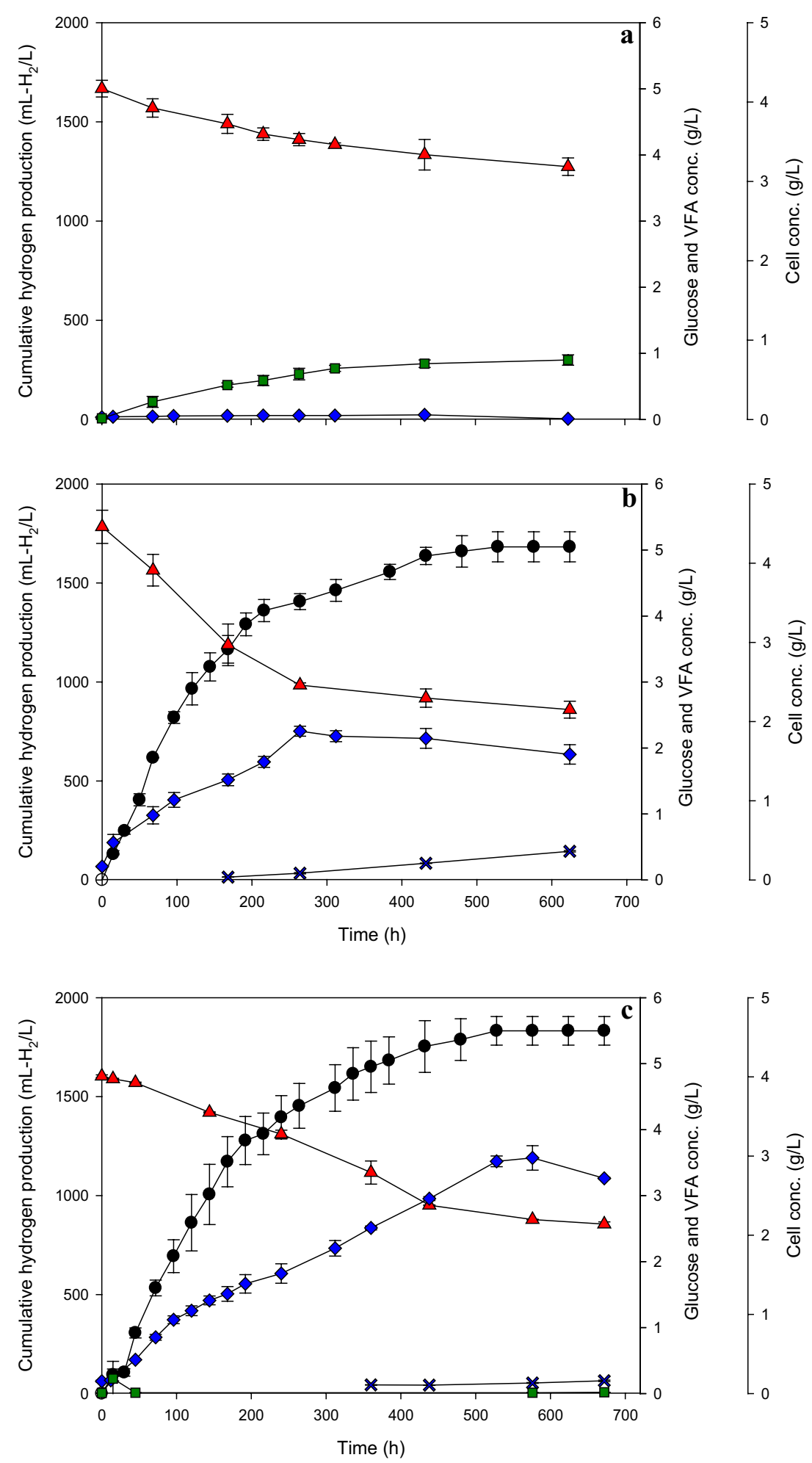

Fig. 2 Variations of cumulative hydrogen production, concentrations of cell, glucose, and volatile fatty acid over time. Lactic acid-producing bacteria $(L A B)$ only $(L A B$ concentration $=0.019 \mathrm{~g} / \mathrm{L})(\mathbf{a})$; purple non-sulfur photosynthetic bacteria (PNSB) only (PNSB concentration $=0.131 \mathrm{~g} / \mathrm{L})(\mathbf{b})$; $L A B /$ PNSB ratio of $1 / 12$ at initial cell concentration of $0.15 \mathrm{~g} / \mathrm{L}$ (LAB concentration $=0.019$, PNSB concentration $=0.131 \mathrm{~g} / \mathrm{L})$ (c). Hydrogen (black circle), glucose (red triangle), cell (blue diamond), lactic acid (green square), formic acid (blue cross) 
by $R$. sphaeroides, but formate was produced as an end-product.

In the experiment with PNSB augmented with LAB (Fig. 2c), the concentration of formic acid in the fermentation broth was less than the treatment with PNSB alone (Fig. 2b). The HY of $5.93 \pm 0.23 \mathrm{~mol} \mathrm{H}_{2} / \mathrm{mol}$ glucose obtained from the PNSB augmented with LAB treatment was higher than the PNSB-alone treatment, $4.38 \pm 0.20 \mathrm{~mol} \mathrm{H}_{2} / \mathrm{mol}$ glucose. The presence of formic acid is probably responsible for a low HY in the PNSBalone treatment due to pyruvate conversion to formate rather than acetyl-CoA, resulting in conservation of less energy (ATP) and a lower concentration of (reduced) $\mathrm{NAD}(\mathrm{P}) \mathrm{H}$ which are important energy and electron carriers used for hydrogen production by photo-fermentative processes [29]. When PNSB was grown alone, cells grew to a stationary phase after $264 \mathrm{~h}$ with a cell concentration of approximately $1.8 \mathrm{~g} / \mathrm{L}$. A small amount of glucose was continuously consumed for hydrogen production in this period (264-624 h). In PNSB augmented with LAB system (Fig. 2c), the amount of bacterial cells was higher than that for LAB alone and PNSB alone. Cell growth continued after $264 \mathrm{~h}$ of fermentation with glucose utilization and hydrogen production. PNSB might be able to use lactic acid as a substrate for cell growth and hydrogen production during this period (264-624 h).

Our results suggested that glucose was used as the major substrate to produce hydrogen by PNSB and a bioaugmentation system. Glucose was consumed and reduced to approximately $2.6 \mathrm{~g} / \mathrm{L}$ in both PNSB-alone and PNSB augmented with LAB systems. Considering an augmentation of LAB into PNSB system, lactate is likely an intermediate being transferred from LAB to PNSB for hydrogen production; therefore, a bioaugmentation system with a presence of potential lactate gave a slightly higher cumulative hydrogen production $\left(1833 \pm 72 \mathrm{~mL} \mathrm{H}_{2} / \mathrm{L}\right.$ ), HY, and HPR (Fig. 2c) than the PNSB alone. These results indicate that the presence of $\mathrm{LAB}$ in the fermentation system is beneficial to hydrogen production in terms of serving lactate as another substrate for hydrogen production.

A low concentration of lactic acid detected in the fermentation broth indicated a suitable LAB/PNSB ratio to balance the rate of lactic acid production and its consumption (Fig. 2c). This result shows that hydrogen production by KKU-PS5 (PNSB) can be improved by the augmentation with TISTR 895 (LAB).

\section{Optimization of initial pH, light intensity, and Mo concentration on HPR by PNSB augmented with LAB} The effects of initial $\mathrm{pH}\left(X_{1}\right)$, light intensity $\left(X_{2}\right)$, and Mo concentration $\left(X_{3}\right)$ on HPR by PNSB augmented with $\mathrm{LAB}$ were examined under the optimal $\mathrm{LAB} / \mathrm{PNSB}$ ratio of $1 / 12$ and initial cell concentration of $0.15 \mathrm{~g} / \mathrm{L}$. The predicted values of the response (HPR) in Table 2 were calculated using a quadratic equation (Eq. 5), which included the main effects, interaction effects, and the squared effects.

$$
\begin{aligned}
Y_{\mathrm{HPR}}= & 8.82-0.40 X_{1}+0.35 X_{2}+0.078 X_{3}-0.012 X_{1} X_{2} \\
& +0.013 X_{1} X_{3}-0.062 X_{2} X_{3}-1.35 X_{1}^{2} \\
& -0.61 X_{2}^{2}-0.32 X_{3}^{2}
\end{aligned}
$$

The coefficient of determination, $R^{2}$, was 0.9178 , suggesting the model could explain $91.78 \%$ of the variation in the response. This indicated a good fit to the experimental data. The $p$ value $(p=0.0003)$ obtained from the regression analysis of variance (ANOVA) was less than 0.05 indicating the significance of the model (Table 3). The significance of each coefficient was determined using probability values. Linear terms of initial $\mathrm{pH}\left(X_{1}\right)$ and light intensity $\left(X_{2}\right)$ showed significant individual effects on HPR $(p \leq 0.05)$, whereas Mo supplementation had no significant effect on HPR $(p=0.6118)$. All of interaction terms $\left(X_{1} X_{2}, X_{1} X_{3}, X_{2} X_{3}\right)$ had $p$ values higher than 0.05 , indicating no significant interaction effects between variables on HPR. The quadratic terms of these three factors $\left(X_{1}^{2}, X_{2}^{2}, X_{3}^{2}\right)$ were significant $(p \leq 0.05)$. The optimal conditions for hydrogen production in bioaugmentation system that maximized HPR were obtained from the analysis of Eq. (5). The predicted maximum response value for HPR was $8.77 \mathrm{~mL} \mathrm{H}_{2} / \mathrm{L} \mathrm{h}$ at an initial $\mathrm{pH}$ of 7.92, light intensity of 8.37 klux, and Mo concentration of $0.44 \mathrm{mg} / \mathrm{L}$.

Response surface plots in three dimensions were developed based on Eq. (5) with one variable being kept constant at its optimal level, and varying the other two parameters over the experimental range (Fig. $3 \mathrm{a}-\mathrm{C}$ ). The highest points in Fig. 3 indicate the optimal conditions for maximal HPR. The HPR increased with the increasing light intensity from 6.00 to 8.37 klux and decreased at light intensities over 8.37 klux (Fig. 3a, c). Light provides ATP and reductive power to the photosynthetic system of photo-fermentative bacteria needed for the hydrogen production process [45]. However, excess light causes a saturation effect, in which ATP and $\mathrm{Fd}_{(\mathrm{red})}$ were excessive for the available nitrogenase [2]. In addition, excess protons generated under high light intensities were captured by photo-fermentative bacteria and dissipated as heat energy, damaging their photosynthetic apparatus [46]. Consequently, a low HPR was obtained at high light intensity. Our previous research found that the optimal light intensity for the strain KKU-PS5 was 6 klux [32]. The higher optimal light intensity, from 6 to 8.37 klux, found in this study may be due to a shading effect of LAB and PNSB in the fermentation broth. 
Table 2 Central composite experimental design (CCD) matrix defining initial pH $\left(X_{1}\right)$, light intensity $\left(X_{2}\right)$, Mo concentration $\left(X_{3}\right)$, and results on hydrogen production rate (HPR)

\begin{tabular}{|c|c|c|c|c|c|c|c|c|}
\hline \multirow[t]{3}{*}{ Run } & \multicolumn{6}{|c|}{ Parameters } & \multicolumn{2}{|c|}{$\mathrm{HPR}\left(\mathrm{ml} \mathrm{H}_{2} / \mathrm{L} \mathrm{h}\right)$} \\
\hline & \multicolumn{2}{|c|}{ Initial pH $\left(X_{1}\right)$} & \multicolumn{2}{|c|}{ Light intensity $\left(X_{2}\right)$} & \multicolumn{2}{|c|}{ Mo concentration $\left(X_{3}\right)$} & \multirow[t]{2}{*}{ Observed } & \multirow[t]{2}{*}{ Predicted } \\
\hline & Code & Actual & Code & Actual (klux) & Code & Actual (mg/L) & & \\
\hline 1 & 0.00 & 8.00 & 0.00 & 8.00 & 0.00 & 0.30 & $8.9 \pm 0.4$ & 8.8 \\
\hline 2 & -1.00 & 7.00 & 1.00 & 10.00 & 1.00 & 0.50 & $7.4 \pm 0.6$ & 7.3 \\
\hline 3 & 0.00 & 8.00 & 0.00 & 8.00 & 0.00 & 0.30 & $8.8 \pm 0.2$ & 8.8 \\
\hline 4 & -1.68 & 6.32 & 0.00 & 8.00 & 0.00 & 0.30 & $5.6 \pm 0.5$ & 5.7 \\
\hline 5 & 0.00 & 8.00 & 1.68 & 11.36 & 0.00 & 0.30 & $7.5 \pm 0.1$ & 7.7 \\
\hline 6 & 0.00 & 8.00 & -1.68 & 4.64 & 0.00 & 0.30 & $5.8 \pm 0.4$ & 6.5 \\
\hline 7 & 0.00 & 8.00 & 0.00 & 8.00 & 0.00 & 0.30 & $8.8 \pm 0.3$ & 8.8 \\
\hline 8 & 1.00 & 9.00 & -1.00 & 6.00 & -1.00 & 0.10 & $6.2 \pm 0.2$ & 5.7 \\
\hline 9 & 0.00 & 8.00 & 0.00 & 8.00 & 0.00 & 0.30 & $9.0 \pm 0.6$ & 8.8 \\
\hline 10 & 0.00 & 8.00 & 0.00 & 8.00 & 0.00 & 0.30 & $9.1 \pm 0.4$ & 8.8 \\
\hline 11 & 1.00 & 9.00 & -1.00 & 6.00 & 0.20 & 0.50 & $6.6 \pm 0.1$ & 6.0 \\
\hline 12 & 1.00 & 9.00 & 1.00 & 10.00 & -1.00 & 0.10 & $6.8 \pm 0.4$ & 6.5 \\
\hline 13 & 0.00 & 8.00 & 0.00 & 8.00 & 0.00 & 0.30 & $8.5 \pm 0.4$ & 8.8 \\
\hline 14 & -1.00 & 7.00 & 1.00 & 10.00 & -1.00 & 0.10 & $7.3 \pm 0.5$ & 7.3 \\
\hline 15 & -1.00 & 7.00 & -1.00 & 6.00 & -1.00 & 0.10 & $6.7 \pm 0.4$ & 6.5 \\
\hline 16 & -1.00 & 7.00 & -1.00 & 6.00 & 1.00 & 0.50 & $7.0 \pm 0.2$ & 6.7 \\
\hline 17 & 1.00 & 9.00 & 1.00 & 10.00 & 1.00 & 0.50 & $7.0 \pm 0.4$ & 6.5 \\
\hline 18 & 0.00 & 8.00 & 0.00 & 8.00 & 1.68 & 0.64 & $7.5 \pm 0.4$ & 8.0 \\
\hline 19 & 1.68 & 9.68 & 0.00 & 8.00 & 0.00 & 0.30 & $3.5 \pm 0.2$ & 4.3 \\
\hline 20 & 0.00 & 8.00 & 0.00 & 8.00 & -1.68 & -0.04 & $7.4 \pm 0.0$ & 7.8 \\
\hline
\end{tabular}

Table 3 ANOVA of the fitting model for hydrogen production rate (HPR)

\begin{tabular}{lccccc}
\hline Source & $\begin{array}{l}\text { Sum } \\
\text { of squares }\end{array}$ & $\boldsymbol{d f}$ & $\begin{array}{l}\text { Mean } \\
\text { of square }\end{array}$ & F-value & $\begin{array}{l}\text { (Probability) } \\
\text { probe }>\boldsymbol{F}\end{array}$ \\
\hline Model & 33.80 & 9 & 3.76 & 12.33 & 0.0003 \\
$X_{1}$ & 2.16 & 1 & 2.16 & 7.09 & 0.0238 \\
$X_{2}$ & 1.66 & 1 & 1.66 & 5.45 & 0.0418 \\
$X_{3}$ & 0.084 & 1 & 0.084 & 0.27 & 0.6118 \\
$X_{1} X_{2}$ & 0.00125 & 1 & 0.00125 & 0.0041 & 0.9502 \\
$X_{1} X_{3}$ & 0.00125 & 1 & 0.00125 & 0.0041 & 0.9502 \\
$X_{2} X_{3}$ & 0.031 & 1 & 0.031 & 0.10 & 0.7553 \\
$X_{1}^{2}$ & 26.28 & 1 & 26.28 & 86.28 & $<0.0001$ \\
$X_{2}^{2}$ & 5.32 & 1 & 5.32 & 17.48 & 0.0019 \\
$X_{3}^{2}$ & 1.52 & 1 & 1.52 & 5.00 & 0.0494 \\
Residual & 3.05 & 10 & 0.30 & & \\
Lack of fit & 2.83 & 5 & 0.57 & 13.16 & 0.0067 \\
Cor total & 36.85 & 19 & & & \\
Coefficient of determination $\left(R^{2}\right)=0.9178$ & & \\
Adjusted determination coefficient (adj $\left.R^{2}\right)=0.8434$ & \\
\hline
\end{tabular}

Hence, higher light intensity is needed for hydrogen fermentation by bioaugmentation system than that by PNSB alone.
Figure $3 \mathrm{a}$ and $\mathrm{b}$ indicates that initial $\mathrm{pH}$ had a great influence on HPR. When the initial $\mathrm{pH}$ increased from 7.00 to 7.92 , the HPR increased and then markedly decreased when initial $\mathrm{pH}$ was further increased over 7.92. This revealed that the suitable initial $\mathrm{pH}$ for hydrogen production from glucose by PNSB augmented with $\mathrm{LAB}$ was 7.92. The initial $\mathrm{pH}$ had a great influence on the lag period of hydrogen production. Kim et al. [47] found that if the fermentation process was started at an optimal initial $\mathrm{pH}$, a short lag phase would be achieved. In this study, during the fermentation process, the $\mathrm{pH}$ was decreased due to the production of lactic and formic acids by both types of bacteria. The final $\mathrm{pH}$ was in the range of 6.7-7.0, when the fermentation was conducted at an initial $\mathrm{pH}$ of 8.0 and 9.0. The final $\mathrm{pH}$ was decreased to about 6.3-6.6 when the initial $\mathrm{pH}$ was 7.0 (Additional file 3). A pH in the range of 6.3-6.6 was found to fall in an optimal $\mathrm{pH}$ range of $\mathrm{LAB}$ metabolism for lactic acid production $[48,49]$ leading to a high lactic acid production rate, causing a $\mathrm{pH}$ drop. This adversely affected photo-fermentative bacterial growth and hydrogen production. When the fermentation process was conducted at a higher initial $\mathrm{pH}$ than 7.92, hydrogen production was decreased due to low proton motive force. Consequently, 

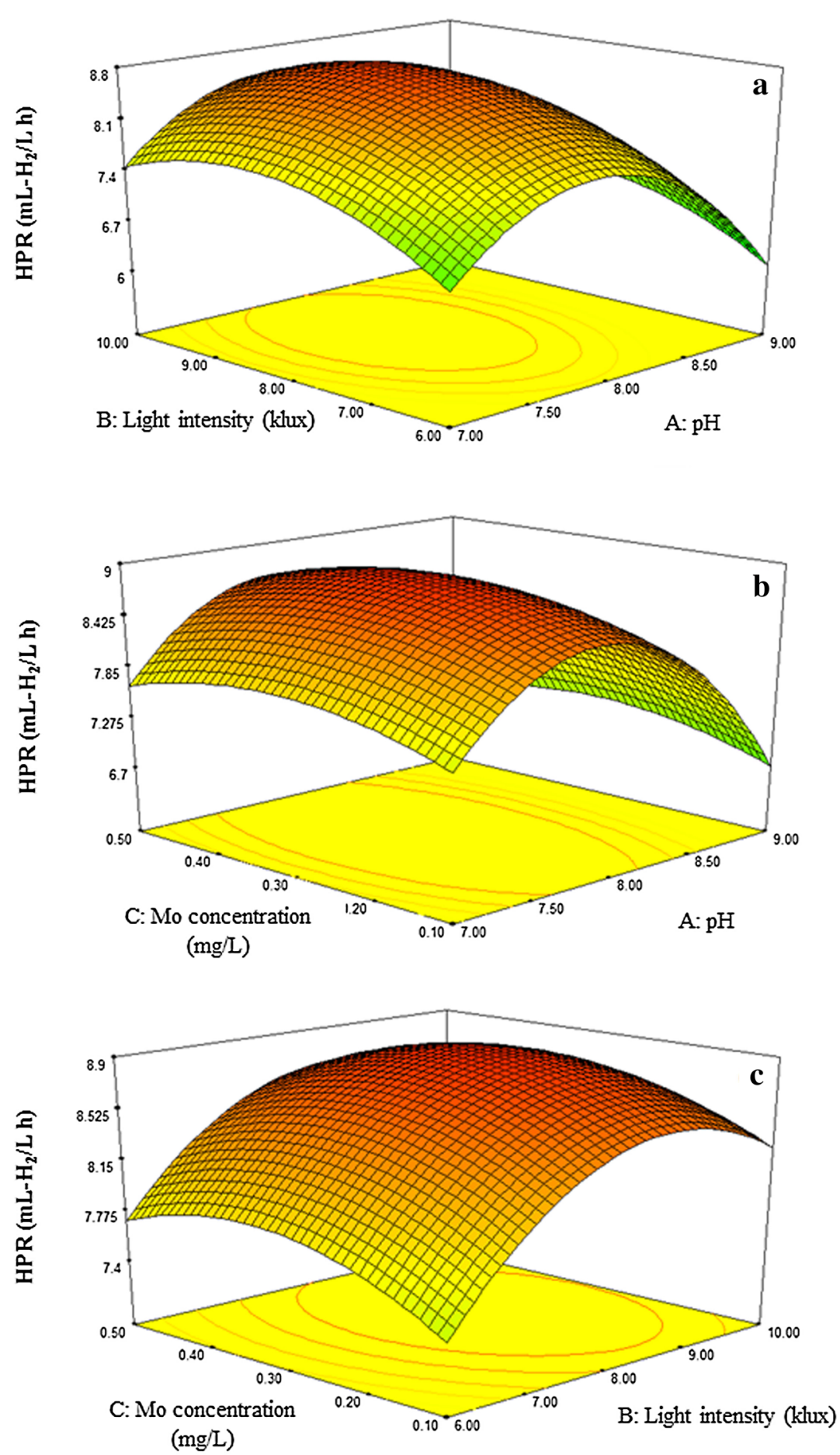

Fig. 3 Response surface plots showing the effects of initial pH, light intensity, and Mo concentration on hydrogen production rate (HPR). The interactive effect of light intensity and $\mathrm{pH}$ at a fixed the amount of Mo concentration of $0.44 \mathrm{mg} / \mathrm{L}$ (a); the interactive effect of $\mathrm{Mo}$ concentration and $\mathrm{pH}$ at a fixed light intensity of $8.37 \mathrm{klux}(\mathbf{b})$; the interactive effect of Mo concentration and light intensity at a fixed pH of 7.92 (c) 
ATP in the cell was lowered inhibiting bacterial growth [50]. In addition, the efficiency of nitrogenase decreases at alkaline $\mathrm{pHs}$ [51] resulting in less hydrogen production. Thus, the $\mathrm{pH}$ of the medium during the fermentation process is considered an important factor for enhancing hydrogen production. When $\mathrm{pH}$ is appropriately controlled, effective hydrogen production can be obtained.

HPR slightly increased with an increase in the amount of Mo supplementation from 0.1 to $0.44 \mathrm{mg} / \mathrm{L}$ (Fig. 3b, c). Availability of Mo was found to be important since it is a required cofactor of Mo-nitrogenase [52, 53] responsible for hydrogen production by photo-fermentative bacteria. Mo-nitrogenases consist of two metalloprotein components, i.e., dinitrogenase or molybdenum-iron (Mo-Fe) protein (encoded by nifD and nif K) and the dinitrogenase reductase or Fe protein (encoded by nifH) [54]. Electron transfer from the Fe protein to the Mo-Fe protein is facilitated by the hydrolysis of ATP molecules involved in hydrogen production mechanisms of Mo-nitrogenases [55]. Mo is a cofactor that is incorporated in Mo-Fe protein and is required for completing the function of Mo-nitrogenase for hydrogen production [55]. This is evidenced by the study of Kars et al. [56] who found that significant nifK gene expression in a medium supplement with Mo resulted in enhanced hydrogen production. However, differences in the optimal Mo concentration were reported. This may have been due to differences in microbial types, culture conditions, and experimental range. An optimal Mo concentration of $0.8 \mathrm{mg} / \mathrm{L}$ was favorable for hydrogen production by Rhodospeudomonas palustris KU003 [57], while Mo concentrations of 0.02 and $1.58 \mathrm{mg} / \mathrm{L}$ were optimal for Rhodobacter capsulatus and R. sphaeroides O.U.001, respectively $[40,56]$.

\section{Confirmation experiment}

The model (Eq. 5) was used to predict optimal initial pH, light intensity, and Mo concentration in order to obtain the maximum HPR. The predicted optimal conditions were an initial $\mathrm{pH}$ of 7.92 , light intensity of $8.37 \mathrm{klux}$, and a Mo concentration of $0.44 \mathrm{mg} / \mathrm{L}$, at which the maximum predicted HPR was $8.8 \mathrm{~mL} \mathrm{H}_{2} / \mathrm{L}$ h. Three replicate batch fermentations with five experiments each were conducted under the optimal, low (run 15), high (run 17), and central conditions (runs 1, 3, 7, 9, 10, 13) (Table 4) to confirm the validity of the model obtained. A cumulative hydrogen production, $\mathrm{HPR}$, and $\mathrm{HY}$ of $3396 \pm 66 \mathrm{~mL} \mathrm{H}_{2} / \mathrm{L}$, $9.1 \pm 0.2 \mathrm{~mL} \mathrm{H}_{2} / \mathrm{L} \mathrm{h}$, and $9.65 \pm 0.23 \mathrm{~mol} \mathrm{H}_{2} / \mathrm{mol}$ glucose, respectively, were obtained under these conditions. The observed HPR was $9.1 \pm 0.2 \mathrm{~mL} \mathrm{H}_{2} / \mathrm{L} \mathrm{h}$ which was within $3.3 \%$ of the predicted value $\left(8.8 \mathrm{~mL} \mathrm{H}_{2} / \mathrm{L} \mathrm{h}\right)$. This indicated high model validity in the CCD experiment.

\section{Comparison of hydrogen production to the literature search}

The HPR and HY in this study were compared with previous reports that used dark- and photo-fermentative bacteria for hydrogen production. The large variations in the HPR in the literature were found in the range of 0.04$100 \mathrm{ml} \mathrm{H}_{2} / \mathrm{L} \mathrm{h}$ (Table 5). The HPR of $9.1 \pm 0.2 \mathrm{~mL} \mathrm{H}_{2} / \mathrm{L} \mathrm{h}$ obtained in this study was markedly higher than that obtained by Kuo et al. [17] and Qin et al. [22]. However, our HPR was lower than that reported by Sivagurunathan et al. [16], Goud et al. [16], and Marone et al. [18]. This was due to the fact that these researchers used darkfermentative bacteria capable of producing hydrogen to enhance HPR. The microorganisms used in the studies included Enterobacter cloacae DSM 16657, Escherichia coli XL1-BLUE, Bacillus subtilis, Pseudomonas stutzeri, Lysinibacillus fusiformis, Buttiauxella sp. 4, Rahnella sp. 10, and Raoultella sp. 47. Therefore, the discrepancy in HPR is due to the type of bacteria, the cultivation conditions, and substrate used.

The HY obtained in this study $\left(9.65 \pm 0.23 \mathrm{~mol} \mathrm{H}_{2} /\right.$ mol glucose) is higher than that reported by Sivagurunathan et al. [23] but could not be compared with other study due the difference in the unit. However, the HY achieved in this study was $80 \%$ of the theoretical HY which is the highest value that has previously been reported. Keasling et al. [58] suggested that a HY of at least $8 \mathrm{~mol} \mathrm{H}_{2} / \mathrm{mol}$ hexose is sufficient for economic applications. The high HY obtained could have been due to the use of glucose as the substrate, which is a less complex carbon source. Another reason was due to the fact

Table 4 Confirmation hydrogen production experiments

\begin{tabular}{|c|c|c|c|c|c|c|c|}
\hline Run & Condition & $\begin{array}{l}\mathrm{X}_{1} \text { initial } \\
\mathrm{pH}\end{array}$ & $\begin{array}{l}X_{2} \text { light intensity } \\
\text { (klux) }\end{array}$ & $\begin{array}{l}X_{3} \text { Mo concentration } \\
(\mathrm{mg} / \mathrm{L})\end{array}$ & $\mathrm{HPR}\left(\mathrm{ml} \mathrm{H}_{2} / \mathrm{Lh}\right)$ & $\begin{array}{l}\mathrm{HY}\left(\mathrm{mol} \mathrm{H}_{2} / \mathrm{mol}\right. \\
\text { glucose })\end{array}$ & $\begin{array}{l}\text { Cumulative } \mathrm{H}_{2} \\
\text { production }\left(\mathrm{ml} \mathrm{H}_{2} / \mathrm{L}\right)\end{array}$ \\
\hline 1 & Optimum & 7.92 & 8.37 & 0.44 & $9.1 \pm 0.2$ & $9.65 \pm 0.23$ & $3396 \pm 66$ \\
\hline 2 & Lower & 7.00 & 6.00 & 0.10 & $6.3 \pm 0.1$ & $8.14 \pm 0.12$ & $2726 \pm 39$ \\
\hline 3 & Upper & 9.00 & 10.00 & 0.50 & $6.9 \pm 0.1$ & $8.20 \pm 0.20$ & $2585 \pm 53$ \\
\hline 4 & Central & 8.00 & 8.00 & 0.30 & $8.7 \pm 0.1$ & $9.46 \pm 0.19$ & $3253 \pm 20$ \\
\hline
\end{tabular}

$H P R$ hydrogen production rate, $H Y$ hydrogen yield 


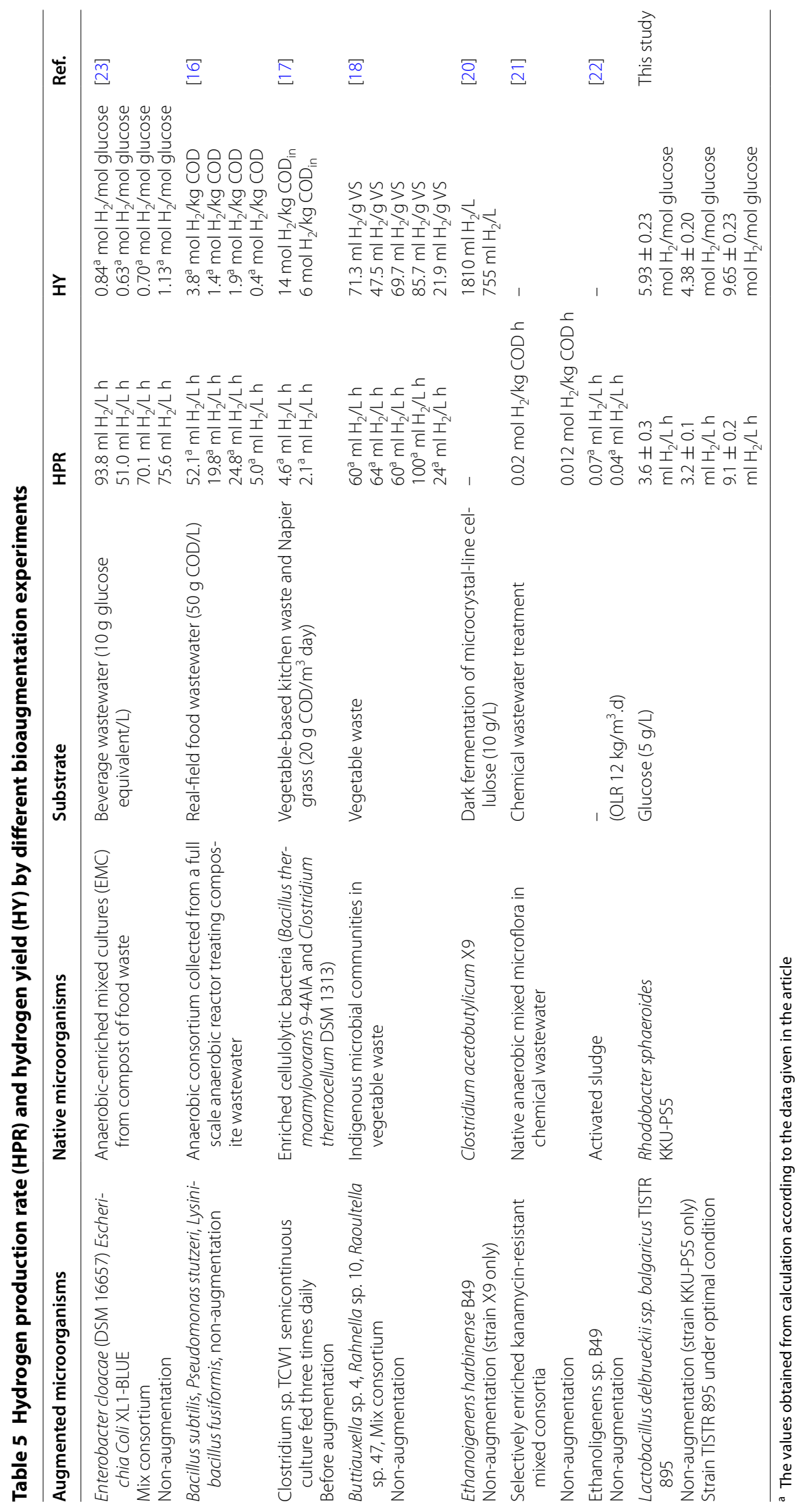


that glucose was fermented to lactic acid by augmented LAB. As we know that lactic acid is a favored substrate for hydrogen production by PNSB, the HY in the LABaugmented PNSB system was relatively high in our study. Our results indicated that by optimizing the key factors affecting hydrogen production of these two bacteria, the maximum hydrogen production could be achieved.

\section{Conclusions}

The ratio of LAB/PNSB and the initial cell concentrations showed interactive effects on the rate of lactic acid production and its consumption. A suitable LAB/PNSB ratio and initial cell concentration could balance lactic acid production rate and its consumption to avoid lactic acid accumulation in the fermentation system. A suitable $\mathrm{LAB} / \mathrm{PNSB}$ ratio and initial cell concentration were found to be $1 / 12(\mathrm{w} / \mathrm{w})$ and $0.15 \mathrm{~g} / \mathrm{L}$, respectively. The optimal initial $\mathrm{pH}$, light intensity, and Mo concentration obtained from RSM with CCD were 7.92, 8.37 klux, and 0.44 mg/L, respectively. Under these optimal conditions, cumulative hydrogen production of $3396 \pm 66 \mathrm{~mL} \mathrm{H}_{2} / \mathrm{L}$ and HPR of $9.1 \pm 0.2 \mathrm{~mL} \mathrm{H}_{2} / \mathrm{L} \mathrm{h}$ were obtained. The observed HPR under the optimal conditions $\left(9.1 \pm 0.2 \mathrm{~mL} \mathrm{H}_{2} / \mathrm{L}\right.$ h) was only $3.33 \%$ different from the predicted HPR value $\left(8.8 \mathrm{~mL} \mathrm{H}_{2} / \mathrm{L} \mathrm{h}\right)$. PNSB augmented with LAB produced hydrogen from glucose with a relatively high HY, $9.65 \pm 0.23 \mathrm{~mol} \mathrm{H}_{2} / \mathrm{mol}$ glucose, i.e., $80 \%$ of the theoretical yield. The augmentation of LAB in the PNSB fermentation system is beneficial to hydrogen production in terms of serving lactate as another substrate for hydrogen production. By using appropriate environmental conditions for a cultivation of dark- and photo-fermentative bacteria, an improvement in hydrogen production can be achieved.

\section{Methods \\ Media}

The de Man, Rogosa, and Sharpe medium (MRS medium) for culturing lactic acid-producing bacteria was purchased from MERCK, Germany. The $\mathrm{pH}$ of the medium was adjusted to 6.8 using $2 \mathrm{~N} \mathrm{NaOH}$ or $2 \mathrm{~N} \mathrm{HCl}$.

The growth medium for culturing PNSB was modified from RCVB medium [59]. The growth medium contained (all in $\mathrm{g} / \mathrm{L}$ ): lactic acid 2, sodium glutamate 0.68 , yeast extract $1, \mathrm{KH}_{2} \mathrm{PO}_{4} 0.4, \mathrm{MgSO}_{4} \cdot 7 \mathrm{H}_{2} \mathrm{O}$ 0.4, $\mathrm{NaCl} 0.4, \mathrm{CaCl}_{2}$ $0.05, \mathrm{FeSO}_{4} 0.0005$ in the form of an Fe-EDTA complex and trace elements $1 \mathrm{~mL}$. The trace elements for the growth medium consisted of (all in mg/L): $\mathrm{ZnCl}_{2} \cdot 7 \mathrm{H}_{2} \mathrm{O}$ 100, $\mathrm{MnCl}_{2} \cdot 4 \mathrm{H}_{2} \mathrm{O} 30, \mathrm{H}_{3} \mathrm{BO}_{3} 300, \mathrm{CoCl}_{2} \cdot 6 \mathrm{H}_{2} \mathrm{O} 200$, $\mathrm{CuCl}_{2} \cdot 2 \mathrm{H}_{2} \mathrm{O} 10, \mathrm{NiCl}_{2} \cdot 6 \mathrm{H}_{2} \mathrm{O} 20$, and $\mathrm{Na}_{2} \mathrm{MoO}_{4} 30$ [58]. The $\mathrm{pH}$ of the growth medium was adjusted to 7.0 using $\mathrm{NaOH}$ (in pellet form).
The hydrogen production medium consisted of (all in $\mathrm{g} / \mathrm{L}$ ): glucose 5 , sodium glutamate $0.68, \mathrm{~K}_{2} \mathrm{HPO}_{4} 2.8$, $\mathrm{KH}_{2} \mathrm{PO}_{4} 3.9, \mathrm{MgSO}_{4} \cdot 7 \mathrm{H}_{2} \mathrm{O} \quad 0.2, \mathrm{CaCl}_{2} 0.075, \mathrm{Na}_{2} \mathrm{MoO}_{4}$ 0.02 , and $\mathrm{FeSO}_{4}$ in the form of an Fe-EDTA complex 0.002 and trace elements $(1 \mathrm{~mL})$. The trace elements for the hydrogen production medium consisted of (all in $\mathrm{mg} / \mathrm{L}$ ): $\mathrm{ZnCl}_{2} \cdot 7 \mathrm{H}_{2} \mathrm{O} \quad 100, \mathrm{MnCl}_{2} \cdot 4 \mathrm{H}_{2} \mathrm{O} 30, \mathrm{H}_{3} \mathrm{BO}_{3} 300$, $\mathrm{CoCl}_{2} \cdot 6 \mathrm{H}_{2} \mathrm{O} 200, \mathrm{CuCl}_{2} \cdot 2 \mathrm{H}_{2} \mathrm{O} 10, \mathrm{NiCl}_{2} \cdot 6 \mathrm{H}_{2} \mathrm{O} 20$ and $\mathrm{Na}_{2} \mathrm{MoO}_{4} 30$.

\section{Bacterial strains and culture conditions}

LAB, L. delbrueckii subsp. bulgaricus TISTR 895, was purchased from the Thailand Institute of Scientific and Technological Research (TISTR), Thailand. It was cultured in MRS medium for 12-14 h under static conditions at $35{ }^{\circ} \mathrm{C}$ in an incubator before being used as seed inoculum.

PNSB, $R$. spaeroides KKU-PS5, was previously isolated from an upflow anaerobic sludge blanket (UASB) bioreactor used to produce methane from a hydrogenogenic effluent [32]. Single colonies of the KKU-PS5 strain were grown in growth medium for 2 days, under 4 klux of light illumination using light emitting diode (LED) lamps, on an incubating shaker at $150 \mathrm{rpm}$. Then, a subculture was made in fresh growth medium and cultivated under the same conditions for $24 \mathrm{~h}$, before being used as seed inoculum.

\section{Optimization of $L A B / P N S B$ ratio and initial cell concentration for bio-hydrogen production}

A full factorial design was used to obtain the optimal $\mathrm{LAB} / \mathrm{PNSB}$ ratios and initial cell concentration for hydrogen production by bioaugmentation system. Dark and light fermentative bacteria were mixed at different ratios, 1:1, 1:2, 1:7, and 1:12 (w/w), for use as seed inocula. The inocula at each LAB/PNSB ratio were added into serum bottles containing hydrogen production medium at different initial cell concentrations $(0.05,0.10,0.15,0.20$ and $0.25 \mathrm{~g} / \mathrm{L}$ ). The serum bottles were incubated at $30{ }^{\circ} \mathrm{C}$, at $150 \mathrm{rpm}$ on an incubating shaker under 4 klux of light illumination using LED lamps. Biogas samples were taken every $15 \mathrm{~h}$ during the first 2 days, then every $24 \mathrm{~h}$ until 16 days, and finally every $48 \mathrm{~h}$ thereafter until the end of fermentation. Fermentation broth was sampled at these intervals to determine the glucose, VFAs, and cell concentrations.

Optimization of key factors affecting hydrogen production by bioaugmentation system

RSM with CCD was used to optimize the key factors affecting hydrogen production from glucose by bioaugmentation system. Twenty experimental runs with three 
replicates (Table 2) were generated. The key factors were initial $\mathrm{pH}$ (unit) $\left(X_{1}\right)$, light intensity (klux) $\left(X_{2}\right)$, and Mo concentration $(\mathrm{mg} / \mathrm{L})\left(X_{3}\right)$. The response was HPR. Design-Expert software (Demo version 7.0, Stat-Ease, Inc., Minneapolis, MN, USA) was used to analyze the regression and graphically depict the experimental data. The quality fit of the model was determined by correlative coefficient value, $R^{2}$, and its statistical significance was checked using the $F$ test.

\section{Bio-hydrogen production}

All batch hydrogen fermentations were conducted in 120$\mathrm{mL}$ serum bottles with $70-\mathrm{mL}$ working volumes. The serum bottles were flushed with argon gas for $5 \mathrm{~min}$ to create an anaerobic condition before being closed with rubber stoppers, capped with aluminum caps, and sterilized in an autoclave at $110{ }^{\circ} \mathrm{C}$ for $28 \mathrm{~min}$. After inoculation, the serum bottles were placed on an incubating shaker running at $150 \mathrm{rpm}$ under continuously lighted conditions using LED lamps. The volume of biogas in the head space of the serum bottles was measured using wetted glass syringes [60]. The biogas composition was analyzed using gas chromatography (GC). All experiments were done in triplicate.

\section{Analytic methods}

Cell concentration was measured using a spectrophotometer (UVmini-1240, Shimadzu, Japan) at $620 \mathrm{~nm}$ for the strain TISTR 895 (1 unit of absorbance was equal to $0.4358 \mathrm{~g}$ dry cell/L) and $660 \mathrm{~nm}$ for the strain KKUPS5 (1 unit of absorbance was equal to $0.3964 \mathrm{~g}$ dry cell/L). Cell concentration of the bioaugmentation system was measured at $660 \mathrm{~nm}$ (1 unit of absorbance was equal to $0.4057 \mathrm{~g}$ dry cell/L). The method to determine dry cell weight $(\mathrm{g} / \mathrm{L})$ was described by Laocharoen and Reungsang [32]. The $\mathrm{pH}$ was measured using a $\mathrm{pH}$ meter (Model pH500, Clean USA).

Hydrogen gas production was determined from measurement of gas composition and content of biogas in the head space of serum bottles. A mass balance was used to calculate the total volume of hydrogen [61]. Biogas compositions were determined using a GC (Shimadzu, GC-2014; Japan) equipped with a thermal conductivity detector (TCD) and a $0.2 \mathrm{~m} \times 3 \mathrm{~mm}$-diameter stainless column packed with Shin carbon (50/80 mesh). The temperatures of the injector port, column oven, and detector were 130,120 , and $140{ }^{\circ} \mathrm{C}$, respectively. Helium was used as the carrier gas at a flow rate of $25 \mathrm{~mL} / \mathrm{min}$.

The concentrations of VFAs were determined using a high-performance liquid chromatograph (HPLC) (Shimadzu, DGU-20; Japan) equipped with a refractive index detector (RID) using an Aminex HPX-87H column. The HPLC conditions followed the method of Laocharoen and Reungsang [32].
$\mathrm{HY}$ ( $\mathrm{mol} \mathrm{H}_{2} / \mathrm{mol}$ substrate) was calculated as the total mol of hydrogen $\left(\mathrm{mol} \mathrm{H}_{2}\right)$ divided by the mol of glucose consumed (mol glucose). The HPR ( $\left.\mathrm{mL} \mathrm{H}_{2} / \mathrm{L} \mathrm{h}\right)$ was calculated from cumulative hydrogen production $\left(\mathrm{mL} \mathrm{H}_{2} / \mathrm{L}\right)$ divided by fermentation time (h).

\section{Additional files}

Additional file 1: Lactic acid concentration at lactic acid-producing bacteria/purple non-sulfur photosynthetic bacteria (LAB/PNSB) ratios of 1/2.

Additional file 2: Lactic acid concentration at lactic acid-producing bacteria/purple non-sulfur photosynthetic bacteria (LAB/PNSB) ratios of 1/7.

Additional file 3: Final $\mathrm{pH}$ at each run in central composite experimental design (CCD).

\section{Abbreviations}

CCD: central composite design; COD: chemical oxygen demand; Fd $\mathrm{Cdd}_{\text {(o) }}$ oxidized ferredoxin; $\mathrm{Fd}_{(\text {red) }}$ : reduced ferredoxin; GC: gas chromatography; HPLC: high-performance liquid chromatography; HPR: hydrogen production rate; HY: hydrogen yield; LAB: lactic acid-producing bacteria; L. delbrueckii: Lactobacillus delbrueckii ssp. bulgaricus TISTR 895; LED: light emitting diode; LH1: light-harvesting complex 1; LH2: light-harvesting complex 2; Mo: molybdenum; Mo-Fe: molybdenum-iron; $\mathrm{NH}^{4+} \mathrm{-N}$ : ammonia nitrogen; $\mathrm{PHAs}$ : polyhydroxyalkanoates; PHB: polyhydroxybutyrate; PNSB: purple non-sulfur photosynthetic bacteria; R. sphaeroides KKU-PS5: Rhodobacter sphaeroides KKU-PS5; RID: refractive index detector; RSM: response surface methodology; TCD: thermal conductivity detector; UASB: upflow anaerobic sludge blanket; VFAs: volatile fatty acids.

\section{Authors' contributions}

SL carried out the optimization of lactic acid-producing bacteria/purple nonsulfur photosynthetic bacteria ratio, bioaugmentation study, and drafted the manuscript. PP helped to revise the manuscript. AR conceived of the study, participated in its design and coordination, and helped to revise the manuscript. All authors read and approved the final manuscript.

\section{Author details}

${ }^{1}$ Department of Biotechnology, Faculty of Technology, Khon Kaen University, Khon Kaen 40002, Thailand. ${ }^{2}$ Research Group for Development of Microbial Hydrogen Production Process from Biomass, Khon Kaen University, Khon Kaen 40002, Thailand.

\section{Acknowledgements}

The authors appreciate the Royal Golden Jubilee Ph.D. Program (Grant No. PHD/0162/2553) for the Ph.D. scholarship awarded to SL. The authors gratefully received the financial support from the National Research Council of Thailand through Khon Kaen University-2558, the Office of the Higher Education Commission, the Fermentation Research Center for Value Added Agricultural Products, Khon Kaen University, and the National Research University Project through the Biofuels Research Cluster-Khon Kaen University, the Office of the Higher Education Commission.

\section{Competing interests}

The authors declare that they have no competing interests.

Received: 24 July 2015 Accepted: 9 November 2015

Published online: 25 November 2015

\section{References}

1. Gregory DP. The hydrogen economy. Sci Am. 1973;228:13-21.

2. Seifert K, Waligorska M, Laniecki M. Hydrogen generation in photobiological process from dairy wastewater. Int J Hydrog Energy. 2010;35:9624-9. 
3. Sen B, Suttar RR. Mesophilic fermentative hydrogen production from sago starch-processing wastewater using enriched mixed cultures. Int J Hydrog Energy. 2012;37:155884-97.

4. Wu TY, Wen Hay JX, Kong LB, Juan JC, Md. Jahim J. Recent advances in reuse of waste material as substrate to produce biohydrogen by purple non-sulfur (PNS) bacteria. Renew Sust Energ Rev. 2012;16:3117-22.

5. Keskin T, Abo-Hashesh M, Hallenbeck PC. Photo fermentative hydrogen production from wastes. Bioresour Technol. 2011;102:8557-68.

6. Oh YK, Mohan Raj S, Jung GY, Park S. Current status of the metabolic engineering of microorganisms for biohydrogen production. Bioresour Technol. 2011;102:8357-67.

7. Basak N, Jana AK, Das D, Saikia D. Photofermentative molecular biohydrogen production by purple-non-sulfur (PNS) bacteria in various modes: the present progress and future perspective. Int J Hydrog Energy. 2014;39:6853-71.

8. Zannoni C, De Philippis R, editors. Microbial bioenergy: hydrogen production. Advances in photosynthesis and respiration. 2014, p. 269-90.

9. Ryu MH, Hull NC, Gomelsky M. Metabolic engineering of Rhodobacter sphaeroides for improved hydrogen production. Int J Hydrog Energy. 2014;39:6384-90.

10. Sakurai H, Masukawa H, Kitashima M, Inoue K. Photobiological hydrogen production: bioenergetics and challenges for its practical application. J Photochem Photobiol C. 2013;17:1-25.

11. Chookaew T, O-Thong S, Prasertsan P. Biohydrogen production from crude glycerol by two stage of dark and photo fermentation. Int J Hydrog Energy. 2015;40:7433-8.

12. Cheng J, Ding L, Xia A, Lin R, Li Y, Zhou J, Cen K. Hydrogen production using amino acids obtained by protein degradation in waste biomass by combined dark- and photo-fermentation. Bioresour Technol. 2015;179:13-9.

13. Laurinavichene TV, Belokopytov BF, Laurinavichius KS, Khusnutdinova AN, Seibert M, Tsygankov AA. Towards the integration of dark- and photo-fermentative waste treatment. 4. Repeated batch sequential darkand photo fermentation using starch as substrate. Int J Hydrog Energy. 2012;37:8800-10.

14. Sagnak R, Kargi F. Hydrogen gas production from acid hydrolyzed wheat starch by combined dark and photo-fermentation with periodic feeding Int J Hydrog Energy. 2011;36:10683-9.

15. Liu BF, Ren NQ, Tang J, Ding J, Liu WZ, Xu JF, et al. Biohydrogen production by mixed culture of photo-and dark-fermentation bacteria. Int J Hydrog Energy. 2010;35:2858-62.

16. Goud RK, Sarkar O, Chiranjeevi P, Venkata Mohan S. Bioaugmentation of potent acidogenic isolates: a strategy for enhancing biohydrogen production at elevated organic load. Bioresour Technol. 2014;165:223-32.

17. Kuo WC, Chao YC, Wang YC, Cheng SS. Bioaugmentation strategies to improve cellulolytic and hydrogen producing characteristics in CSTR intermittent fed with vegetable kitchen waste and napier grass. Energy Procedia. 2012;29:82-91.

18. Marone A, Massini G, Patriarca C, Signorini A, Varrone C, Izzo G. Hydrogen production from vegetable waste by bioaugmentation of indigenous fermentative communities. Int J Hydrogen Energy. 2012;37:5612-22.

19. Ma F, Guo JB, Zhao LJ, Chang CC, Cui D. Application of bioaugmentation to improve the activated sludge system into the contact oxidation system treating petrochemical wastewater. Bioresour Technol. 2009:100:597-602.

20. Wang A, Ren N, Shi Y, Lee DJ. Bioaugmented hydrogen production from microcrystalline cellulose using co-culture Clostridium acetobutylicum X9 and Ethanoigenens harbinense B49. Int J Hydrog Energy. 2008;33:912-7.

21. Venkata Mohan S, Mohanakrishna G, Raghavulu SV, Sarma PN. Enhancing biohydrogen production from chemical wastewater treatment in anaerobic sequencing batch biofilm reactor (AnSBBR) by bioaugmenting with selectively enriched kanamycin resistant anaerobic mixed consortia. Int J Hydrog Energy. 2007;32:3284-92.

22. Qin Z, Ren NQ, Li JZ. Bioaugmentation of hydrogen producing bacteria on operation of biohydrogen producing reactor. J Environ Sci (in Chinese). 2007:28:2843-8.

23. Sivagurunathan P, Gopalakrishnan K, Lin CY. Enhancement of fermentative hydrogen production from beverage wastewater via bioaugmentation and statistical optimization. Curr Biochem Eng. 2014;1:92-8.
24. Lo YC, Chen CY, Lee CM, Chang JS. Photo fermentative hydrogen production using dominant components (acetate, lactate, and butyrate) in dark fermentation effluents. Int J Hydrog Energy. 2011;36:14059-68.

25. Zong W, Yu R, Zhang P, Fan M, Zhou Z. Efficient hydrogen gas production from cassava and food waste by a two-step process of dark fermentation and photo-fermentation. Biomass Bioenerg. 2009;33:1458-63.

26. Argun $\mathrm{H}$, Kargı $\mathrm{F}$, Kapdan I. Effects of the substrate and cell concentration on bio-hydrogen production from ground wheat by combined dark and photo-fermentation. Int J Hydrog Energy. 2009;34:6181-8.

27. Verlinden RAJ, Hill DJ, Kenward MA, Williams CD, Radecka I. Bacterial synthesis of biodegradable polyhydroxyalkanoates. J Appl Microbiol 2007;102:1437-49.

28. Kim DH, Son H, Kim MS. Effect of substrate concentration on continuous photo-fermentative hydrogen production from lactate using Rhodobacter sphaeroides. Int J Hydrog Energy. 2012;37:15483-8.

29. Oh YK, Raj SM, Jung GY, Park S. Current status of the metabolic engineering of microorganisms for biohydrogen production. Bioresour Technol. 2011;102:8357-67.

30. Axelsson L. Lactic acid bacteria: classification and physiology. In: Salminen S, Von Wright A, editors. Lactic acid bacteria: microbiology and functional aspects. 2nd ed. New York: Marcel Dekker, Inc; 1998. p. 1-72.

31. Hammes WP, Vogel RF. The genus Lactobacillus. In: Wood BJB, Holzapfel WH, editors. The genera of lactic acid bacteria. London: Chapman and Hall. 1995. p. 19-54.

32. Laocharoen S, Reungsang A. Isolation, characterization and optimization of photo-hydrogen production conditions by newly isolated Rhodobacter sphaeroides KKU-PS5. Int J Hydrog Energy. 2014;39:10870-82.

33. Wang $Y$, Tashiro $Y$, Sonomoto K. Fermentative production of lactic acid from renewable materials: recent achievements, prospects, and limits. J Biosci Bioeng. 2015;119:10-8.

34. Chen CY, Liu CH, Lo YC, Chang JS. Perspectives on cultivation strategies and photobioreactor designs for photo-fermentative hydrogen production. Bioresour Technol. 2011;102:8484-92.

35. Kargi F, Ozmihci S. Effects of dark/light bacteria ratio on bio-hydrogen production by combined fed-batch fermentation of ground wheat starch. Int J Hydrog Energy. 2010;34:869-74.

36. Phowan P, Danvirutai P. Hydrogen production from cassava pulp hydrolysate by mixed seed cultures: effects of initial $\mathrm{pH}$, substrate and biomass concentrations. Biomass Bioenerg. 2014;64:1-10.

37. Idris A, Suzana W. Effect of sodium alginate concentration, bead diameter, initial $\mathrm{pH}$ and temperature on lactic acid production from pineapple waste using immobilized Lactobacillus delbrueckii. Process Biochem. 2006;41:1117-23.

38. Li X, Wang Y, Zhang S, Chu J, Zhang M, Huang M, et al. Effects of light/dark cycle, mixing pattern and partial pressure of $\mathrm{H}_{2}$ on biohydrogen production by Rhodobacter sphaeroides ZX-5. Bioresour Technol. 2011;102:1142-8.

39. Koku H, Eroğlu I, Gündüz U, Yücel M, Türker L. Aspects of the metabolism of hydrogen production by Rhodobacter sphaeroides. Int J Hydrog Energy. 2002;27:1315-29.

40. Afsar N, Özgür E, Gürgan M, de Vrije T, Yücel M, Gündüz U, Eroglu I. Hydrogen production by $R$. capsulatus on dark fermenter effluent of potato steam peel hydrolysate. Chem Eng Trans. 2009;18:385-90.

41. Kapdan IK, Kargi F. Bio-hydrogen production from waste materials. Enzyme Microb Tech. 2006;38:569-82.

42. Lazaro CZ, Varesche MBA, Silva EL. Effect of inoculum concentration, $\mathrm{pH}$, light intensity and lightingregime on hydrogen production by phototrophic microbial consortium. Renew Energ. 2015;75:1-7.

43. Argun H, Kargı F, Kapdan I. Hydrogen production by combined dark and light fermentation of ground wheat solution. Int J Hydrog Energy. 2009;34:4305-11.

44. Eroğlu I, Tabanoğlu A, Gündüz U, Eroğlu E, Yücel M. Hydrogen production by Rhodobacter sphaeroides O.U.001 in a flat plate solar bioreactor. Int $J$ Hydrog Energy. 2008;33:531-41.

45. Kim NJ, Lee JK, Lee CG. Pigment reduction to improve photosynthetic productivity of Rhodobacter sphaeroides. J Microbiol Biotechnol. 2004;14:442-9.

46. Zhang C, Zhu X, Liao Q, Wang Y, Li J, Ding Y, et al. Performance of a groove-type photobioreactor for hydrogen production by immobilized photosynthetic bacteria. Int J Hydrog Energy. 2010;35:5284-92. 
47. Kim DH, Kim SH, Jung KW, Kim MS, Shin HS. Effect of initial pH independent of operational pH on hydrogen fermentation of food waste. Bioresour Technol. 2011;102:8646-52.

48. Hofvendahl K, Hahn-Hägerdal B. Factors affecting the fermentative lactic acid production from renewable resources. Enzyme Microb Technol. 2000:26:87-107.

49. Mussatto SL, Fernandes M, Mancilha IM, Roberto IC. Effects of medium supplementation and $\mathrm{pH}$ control on lactic acid production from brewer's spent grain. Biochem Eng J. 2008;40:437-44.

50. Bowles LK, Ellefson WL. Effects of butanol on Clostridium acetobutylicum. Appl Environ Microbiol. 1985;50:1165-70.

51. Tsygankov AS, Serebryakova LT, Sveshnikov DA, Rao KK, Gogotov IN, Hall DO. Hydrogen photo production by three different nitrogenases in whole cells of Anabaena variabilis and the dependence on $\mathrm{pH}$. Int J Hydrog Energy. 1997;22:859-67.

52. Dixon R, Kahn D. Genetic regulation of biological nitrogen fixation. Nat Rev Microbiol. 2004;2:621-31.

53. Eroglu E, Melis A. Photobiological hydrogen production: recent advances and state of the art. Bioresour Technol. 2011;102:8403-13.

54. Tan JW, Thong KL, Arumugam ND, Cheah WL, Lai YW, Chua KH, et al. Development of a PCR assay for the detection of nifH and nifD genes in indigenous photosynthetic bacteria. Int J Hydrog Energy. 2009;34:7538-41.
55. Willison JC, Jouanneau Y, Colbeau A, Vignais PM. $\mathrm{H}_{2}$ metabolism in photosynthetic bacteria and relationship to $\mathrm{N}_{2}$ fixation. Ann Microbiol (Inst Pasteur). 1983;134:115-35.

56. Kars G, Gündüz U, Yücel M, Türker L, Eroglu I. Hydrogen production and transcriptional analysis of nifD, nifK and hupS genes in Rhodobacter sphaeroides $0 . \cup .001$ grown in media with different concentrations of molybdenum and iron. Int J Hydrog Energy. 2006;31:1536-44.

57. Prashanthi Y, Garimella S, Kudle KR, Merugu R. Effect of light intensity and metal ions on the production of hydrogen by the purple non Sulphur bacterium Rhodospeudomonas palustris KU003. Int J Res Environ Sci Technol. 2014;4:61-4.

58. Keasling JD, Benemann JR, Pramanik J, Carrier TA, Jones KL, Van Dien SJ. A toolkit for metabolic engineering of bacteria: application to hydrogen production. In: Zaborski OR, Benemann JR, Matsunaga T, Miyake J, San Pietro A, editors. Biohydrogen. New York: Plenum Press. 1997. p. 87.

59. Biebl H, Pfennig N. Isolation of members of the family Rhodospirillaceae. In: Starr MP, Stolp H, Truper HG, Balows A, Schegel HG, editiors. The prokaryotes, vol 1. New York: Springer. 1981. p. 267-73.

60. Owen W, Stuckey C, Healy J, Young L, McCarty P. Bioassay for monitoring biochemical methane potential and anaerobic toxicity. Water Res. 1978;13:485-93.

61. Zheng XJ, Yu HQ. Inhibitory effects of butyrate on biological hydrogen production with mixed anaerobic cultures. J Environ Manage. 2005;74:65-70.

\section{Submit your next manuscript to BioMed Central and take full advantage of:}

- Convenient online submission

- Thorough peer review

- No space constraints or color figure charges

- Immediate publication on acceptance

- Inclusion in PubMed, CAS, Scopus and Google Scholar

- Research which is freely available for redistribution

Submit your manuscript at 